University for Business and Technology in Kosovo

UBT Knowledge Center

Nov 7th, 9:00 AM - 5:00 PM

\title{
The Interrelationship between Financial Attitude, Financial Behavior and Financial Knowledge
}

Dorjana Nano

University Eqrem Çabej, nano.dori@yahoo.com

Follow this and additional works at: https://knowledgecenter.ubt-uni.net/conference

Part of the Business Commons

\section{Recommended Citation}

Nano, Dorjana, "The Interrelationship between Financial Attitude, Financial Behavior and Financial Knowledge" (2015). UBT International Conference. 15.

https://knowledgecenter.ubt-uni.net/conference/2015/all-events/15

This Event is brought to you for free and open access by the Publication and Journals at UBT Knowledge Center. It has been accepted for inclusion in UBT International Conference by an authorized administrator of UBT Knowledge Center. For more information, please contact knowledge.center@ubt-uni.net. 


\title{
The Interrelationship between Financial Attitude, Financial Behavior and Financial Knowledge
}

\author{
Dorjana Nano \\ University "Eqrem Çabej“, Albania, Gjirokastër \\ nano.dori@yahoo.com
}

\begin{abstract}
Financial literacy is shown to be an important life skill for people. It influences people every day financial decisions and has a macro impact on the economy and financial satisfaction of the society. Studies revealed financial literacy to cover three dimensions: financial knowledge, financial attitude and financial behavior. This research aims to examine the interrelationship between the three components of financial literacy. The main objectives of the current research are: a) firstly, to provide some evidences of the existing literature on the linkage between financial knowledge, financial attitude and financial behavior; b) secondly, to inspect this association in the case of Albanian university students; c) thirdly, to investigate the mediating effect of financial attitude on the connection between financial knowledge and financial behavior; d) finally, to present some conclusions and recommendation for parents, school and future researchers. The main research questions addressed in this study are: 1) Is there any relationship between students' financial knowledge and their financial attitude and behavior in the case of Albania? 2) Does financial attitude serve as a mediator factor between financial knowledge and financial behavior? The database for this investigation is provided by a survey conducted on 637 students from eight universities in Albania and is part of my dissertation study. Person correlation technique and linear regression model will be employed to analyse the database. Results of this study demonstrate a statistically significant relationship between the three components of financial literacy. In addition, financial attitude is discovered to play a mediating effect on the association between financial knowledge and financial behavior. Future research can be undertaken to explore whether financial knowledge serves as a mediator in the linkage between financial attitude and financial behavior.
\end{abstract}

Keywords: Financial Attitude, Financial Behavior, Financial Knowledge, Mediator

\section{Introduction}

Financial literacy is revealed to be an essential skill for people. Individuals' financial literacy not only affects their lifestyle and financial welfare, but it has a substantial impact on the economy, society and the financial system as well. Vitt et al., in [7] define financial literacy as: "The ability to read, analyze, manage, and communicate about the personal financial conditions that affect material well being. Financial literacy includes the ability to discern financial choices, discuss money and financial issues without (or despite) discomfort, plan for the future, and respond competently to life events that affect everyday financial decisions, including events in the general economy". In concert with this definition, studies demonstrate that financial literacy consists of three main dimensions: financial knowledge, financial attitude and financial behaviour. A financially educated person must be familiar with some fundamental financial concepts like: lending and borrowing, insurance, investments and savings; ought to have a positive mindset towards personal finances and also must show reasonable financial behaviour. King in [5] highlights that "knowledge, behavior and attitude serve as a foundation for wisdom". Many researchers have studied students' financial capability and discovered an interrelationship between financial knowledge, attitude and behaviour. According De Vaney in [3] enhanced financial knowledge results on better money attitude. Meanwhile, having a positive outlook towards personal finances and business in general, help people to achieve financial success (Hayhoe, Norvilitis) in ([4] and [6]). Chen and Volpe in [2] conducted an investigation on 924 college students to explore their financial literacy and discovered better financial knowledgeable students to display superior money behaviours towards saving, investing, lending and borrowing. They also found that a 
healthier money attitude and behaviour was statistically significant correlated with improved financial knowledge. This analyzing method was adopted by other researchers Beal and Delpachitra in [1] sought to investigate personal financial knowledge and skills of university students. Authors surveyed 837 first-year university students at a regional Australian university seeking to provide evidence about the level of financial knowledge and skills of university students. They revealed financial illiteracy among university students. Authors highlighted that poor financial skills could be explained by the lack of a sound financial program. The question is whether this interrelationship stands in the case Albania?

This research seeks to provide evidence on the interrelatedness between financial knowledge, financial attitude and financial behavior in the case of Albanian university students. The major objectives of the study are: firstly, to present some foreign evidences on the correlation among the three components of financial literacy; secondly, to examine whether there is any relationship among financial knowledge, financial attitude and financial behavior in the case of Albanian students; thirdly, to investigate whether financial attitude serve as a mediator factor between students financial knowledge and their behavior; finally, to discuss and present some recommendation to improve the level of the three dimensions of financial literacy. The main research questions raised in this research are:

- Is there any relationship between students' financial knowledge and their financial attitude and behaviour?

- Does financial attitude serve as a mediator factor between financial knowledge and financial behaviour?

\section{Research Methodology}

The current study is based on a research conducted as a purpose of my dissertation defense in the field of finance. The database is provided by undertaken a survey on 637 students from eight universities in Albania. The questionnaire comprised 42 questions testing students' knowledge on financial concepts, their attitude towards money management and students financial behavior. Other 17 questions gathered information about participants' profile. The questionnaire is tested for its validity and consistency. The response rate of return consisted of $95 \%(607 / 637)$. In order to make the relevant analysis, a score is calculated for each component of financial literacy. The Pearson correlation is utilized to explore whether there is any significant correlation between financial knowledge, attitude and behavior. Three different variables are considered in this analysis: the sum score of students' financial knowledge, the mean value of financial behavior and the mean value of financial attitude. These values are assessed according to the Likert scale evaluation based on a five range scale. The second research question, exploring the mediator effect of financial attitude on financial knowledge and behavior, is initially analyzed by employing a linear regression with financial attitude as the dependant variable and financial knowledge as the independent one. Then, a two stage hierarchic regression is performed considering financial behavior as the dependant variable and financial knowledge as the predictor in the first step, whereas in the second phase, financial knowledge is used as dependant variable, while financial attitude as independent one.

\section{Data Analyzing and Findings}

As mentioned in the methodology section, the Pearson correlation coefficient will determine whether students with more points in financial literacy or financial position, have more points on financial behavior. In other words, students who have more financial knowledge or best approach to personal finance should show better financial behavior. Meanwhile, the regression model will verify whether increasing financial knowledge will improve students' financial attitude, which in turn will result in better financial behavior.

- $\quad$ Research Question 1: Is there any relationship between students' financial knowledge and their financial attitude and behaviour?

Results of the Pearson correlation demonstrate a statistically significant link between financial behavior and financial attitude $(r=0.415, \mathrm{p}=.000)$. Whereas, the relation between financial behavior 
and financial knowledge appears weak, but statistically significant $(r=0,108, p=.000)$. The same result is shown to be between the financial literacy and financial attitude, based on $99 \%$ confidence level $(r=0.055, p=0.009)$. The importance of the relationship between variables is determined based on the $\mathrm{p}$ value, which must be equal to or less than 0.05 . In this case, the three links meet this criterion. Table 1 below represents the results of the correlation matrix for financial behavior, attitude and financial knowledge.

Table 1. The Matrix Correlation

\begin{tabular}{||l|c|c|}
\hline & Pearson Correlation & $\mathbf{p}$ \\
\hline Financial Behavior and Financial Attitude & 0.415 & .000 \\
\hline Financial Behavior and Financial Knowledge & 0.108 & .000 \\
\hline Financial Knowledge and Financial Attitude & 0.055 & .009 \\
\hline
\end{tabular}

Results demonstrate that there is a statistically significant relationship between students' financial behavior, financial attitude and their financial knowledge. This result poses another question: Does variable "financial attitude" serve as an intermediary factor in the relationship between financial knowledge and financial behavior? In other words, does a student with a particular approach to personal finance, present a better financial behavior, if it has better financial knowledge?

- Research Question 2: Does financial attitude serve as a mediator factor between financial knowledge and financial behaviour?

To analyze the link above is primarily considered a linear regression with dependent variable financial attitude and predictor financial knowledge. Then a hierarchic regression model is performed, considering financial behavior as the dependant variable and financial knowledge as the predictor in the first step, whereas in the second phase, financial knowledge is used as dependant variable, while financial attitude as independent one. The results are presented in the following table.

Table 2: Hierarchic Regression

\begin{tabular}{|c|c|c|c|c|c|c|}
\hline \multicolumn{2}{|c|}{ Model } & $\mathbf{R 2}$ & $\mathbf{F}$ & Sig. F & $\boldsymbol{\beta}$ & $\rho$ \\
\hline 1 & $\begin{array}{lr}\text { Regression: } & \text { Financial } \\
\text { Knowledge } & \text { on } \\
\text { Financial Attitude } & \end{array}$ & 0.003 & 6.787 & 0.009 & 0.055 & $0.009<0.05$ \\
\hline 2 & $\begin{array}{lr}\text { Regression: Financial } \\
\text { Knowledge } & \text { on } \\
\text { Financial Behavior }\end{array}$ & 0.012 & 27.016 & 0.000 & 0.108 & $\begin{array}{r}.000<0.0 \\
5\end{array}$ \\
\hline 3 & $\begin{array}{lr}\text { Regression: } & \text { Financial } \\
\text { Attitude on } & \text { Financial } \\
\text { Behavior } & \text { when } \\
\text { controlling } & \text { for } \\
\text { Financial Knowledge }\end{array}$ & 0.179 & 248.454 & 0.000 & 0.086 & $\begin{array}{r}.000<0.0 \\
5\end{array}$ \\
\hline
\end{tabular}

All three models result significant with $99 \%$ confidence level. Statistics demonstrate that standardized coefficient for variable financial knowledge is reduced to 0.022 (0108-0086). This result indicates that the financial attitude partially mediates the relationship between financial knowledge and financial behavior. So the financial knowledge has a direct impact on financial behavior, but the relationship is influenced by the attitude to personal finance. So, a student with very good financial knowledge will not necessarily provide a good financial behavior, as the result will depend on the student's attitude toward personal finance. The diagram below shows the model of financial intermediation position. 


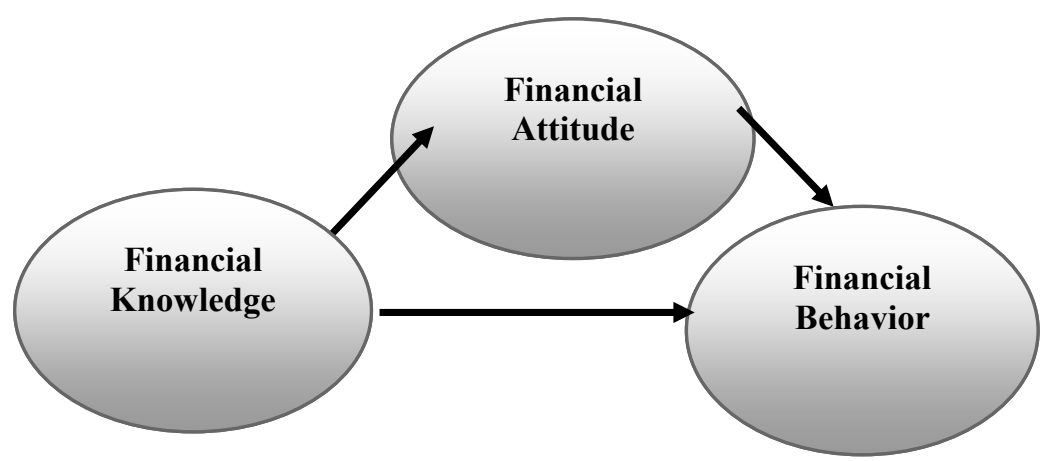

Figure 1: Financial Knowledge intermediating in Financial Position

\section{Conclusions and Recommendations}

This study examined the interrelation between financial knowledge, financial behavior and financial attitude. The current research is focused on Albanian university students. Results of the Pearson technique discovered that students who had more points on financial knowledge, had more points on financial behavior and financial attitude. Also, students who had more points on the financial attitude had more points in financial behavior. The statistics proved a statistically significant linkage between the three components of financial literacy. Exploring the role of financial attitude on the connection between financial knowledge and financial behavior, it is found evidence on the mediating effect on this association. Hence, a student with the best financial knowledge does not display automatically best financial behavior, since it is depending on its mindset towards personal finances. Results of this study suggest the importance of students' financial attitude on money management skills and behavior. It is imperative for parents and schools to help students develop good money attitude. Otherwise, they will be more influenced from the marketing world, mass media or other sources that maybe predict unreasonable spending. Future research can be undertaken to study the mediating effect of financial knowledge in the relation between financial attitude and financial knowledge. Exploring this influence would be valuable in order to understand whether a student with a specific attitude towards personal finances would improve its financial behavior in the case of increased financial knowledge.

\section{References}

1. Beal J. D, Delpachitra B. Sarath.: Financial Literacy among Australian University Students. Journal of Economic Papers, (2003), 22(1): 65-78.

2. Chen, H., Volpe, R. P., An Analysis of Personal Financial Literacy among College Students. Financial Services Review, (1998) 7(2): 107-128.

3. Devaney, S. A., Gorham, L., Bechman, J. C., Haldeman, V. A.: Cash Flow Management and Credit Use: Effect of A Financial Information Program. Journal of Financial Counseling and Planning, (1996) 7: $71-79$

4. Hayhoe, C. R., Leach, L. J., Turner, P. R., Bruin, M. J., Lawrence, F. C.: Differences in Spending Habits and Credit Use of College Students. Journal of Consumer Affairs, (2000) 34 (1): 113-133

5. King, P. M.: Student Learning In Higher Education. In S. R. Komives, D. B. Woodard, Jr., \& Associates (Eds.), Student Services: A Handbook For The Profession, 4th Ed., San Francisco: Jossey-Bass, 2003

6. Norvilitis, J. M., Szablicki, P. B., Wilson, S. D.: Factors Influencing Levels of Credit Card Debt in College Students. Journal of Applied Social Psychology, (2003) 33: 935-947

7. Vitt, L., Anderson, C., Kent, J., Lyter, D., Siegenthaler, J. Ward, J.: Personal Finance and the Rush to Competence: Financial Literacy Education in the US' National Field Study Commissioned by the Fannie Mae Foundation, Institute for Socio-Financial Studies (2000) 